\title{
PREVALENCE AND ANTIBACTERIAL SUSCEPTIBILITY TESTING PATTERN OF BACTERIAL PATHOGENS CAUSING URINARY TRACT INFECTIONS IN COMMUNITY
}

\author{
Vellanki Naga Madhavi1, Puppala Subbulu²
}

${ }^{1}$ Assistant Professor, Department of Microbiology, Katuri Medical College and Hospital, Guntur.

${ }^{2}$ Associate Professor, Department of Microbiology, Katuri Medical College and Hospital, Guntur.

ABSTRACT
BACKGROUND
To determine the prevalence and antimicrobial susceptibility pattern of isolated bacteria from suspected urinary tract
infections in the community.
Urinary Tract Infection (UTI) is a term applied to a variety of conditions ranging from asymptomatic presence of bacteria in the
urine to severe infection of the kidney with sepsis.

\section{METHODS}

Mid-stream urine samples were collected in aseptic conditions and processed. The organisms were identified based on cultural characteristics, microscopy and biochemical reactions. The antibiotic susceptibility testing was done by Kir by Bauer disc diffusion method.

\section{RESULTS}

Out of 401 samples, bacterial isolates were positive for 43 samples. Among them most prevalent organism is Escherichia coli followed by Klebsiella pneumoniae, Enterococcus, Staphylococcus, Pseudomonas and Proteus Spp.

\section{CONCLUSION}

In this study most of the organisms are resistant against ampicillin and sensitive against nitrofurantoin and amikacin. So the empirical treatment of the UTI patients with these drugs can give immediate recovery from the infection, so that further systemic spread of the infection can be prevented.

\section{KEYWORDS}

UTI, Antibiotic Susceptibility Test, Kirby Bauer Disc Diffusion Method.

HOW TO CITE THIS ARTICLE: Madhavi VN, Subbulu P. Prevalence and antibacterial susceptibility testing pattern of bacterial pathogens causing urinary tract infections in community. J. Evolution Med. Dent. Sci. 2016;5(30):1528-1531,

DOI: $10.14260 /$ jemds/2016/360

\section{INTRODUCTION}

Urinary Tract Infections (UTIs) are the second most common infections in community. Incidence of UTI is higher in women than men because of short urethra, absence of prostatic secretions, pregnancy and easy contamination of urinary tract with faecal flora.(1) It has been estimated that 150 million people were infected with UTI per annum worldwide, which is costing global economy more than 6 billion US dollars.(2)

An estimated $50 \%$ of women experience at least one episode of UTI at some point in their lifetime and between $20 \%$ and $40 \%$ of women have recurrent episodes. Approximately, $20 \%$ of all UTIs occur in men.(3) UTI may be defined as a condition in which bacteria are established and multiplying within the urinary tract. Diagnosis requires demonstration of bacteriuria. Exceptions to this include patients with pyogenic abscess of kidney or perinephric tissue, obstructed pyonephrosis or bacterial prostatitis in whom the urine may be sterile. Some definitions are necessary because the infection of the urinary tract may result from microbial invasion of any of the tissues extending from urethral orifice to the renal cortex. ${ }^{(4)}$

Financial or Other, Competing Interest: None.

Submission 05-03-2016, Peer Review 20-03-2016,

Acceptance 23-03-2016, Published 12-04-2016.

Corresponding Author:

Dr. Vellanki Naga Madhavi,

House No. 3-29-39/15/3,

Chandana Residency, Krishnanagar, $6^{\text {th }}$ Lane,

Guntur-522006, Andhra Pradesh.

E-mail:mkakumanu2@gmail.com

DOI: $10.14260 /$ jemds $/ 2016 / 360$
Urinary tract infection is said to exist when pathogenic microorganisms are detected in the urine, urethra, bladder, kidney or prostate with or without the presence of specific symptoms. In most instances, growth of more than $10^{5}$ organisms per millilitre from a properly collected midstream "Clean-Catch" urine sample indicates infection.(5) UTI is a bacterial infection affecting urinary tract. When bacteria from the rectal area enter the urinary tract via the urethra to the bladder and multiplies in the urine, an infection occurs. In many cases bacteria first travel to the urethra and when they get multiplied an infection can occur. An infection limited to the urethra is called urethritis. If bacteria move to the bladder and multiply, bladder gets infected and it is called cystitis. If the infection is not treated promptly, bacteria may then travel further up the ureters to multiply and infect the kidneys called pyelonephritis.(6)

The patients with UTI shows signs and symptoms like burning pain on urination, urinary frequency or urgency, urinary incontinence, blood in the urine, foul-smelling urine, and fever with chills in cases of more serious infection.(7) Patients with sexually transmitted infections as well as urethritis, cervicitis and vulvovaginitis from other causes can present with symptoms similar to cystitis. Some patients with ureterolithiasis may have only mild flank pain or lower urinary tract symptoms. Pelvic inflammatory disease, appendicitis and sigmoid diverticulitis are among the entities which have been misdiagnosed as acute cystitis.(8) Acute UTI is one of the most important causes of morbidity, occasionally becoming life-threatening, forcing the general population to seek medical attention and accounting for considerable health care costs. Wide spectrums of organisms are 
implicated in its aetiology, the most common being Escherichia coli and other gram negative bacteria followed by gram positive organisms. $(9,10)$

\section{MATERIALS AND METHODS}

The present study was conducted in patients attending outpatient department in our hospital. It was a prospective study, which was done in duration of 6 months' period. Patients attending different clinical OP departments with signs and symptoms of UTI were selected for the study, as this work is aimed to assess the prevalence and antibiogram of bacterial pathogens causing UTI in the community. Clean catch midstream urine samples were collected from each patient in a $20 \mathrm{~mL}$ calibrated sterile screw-capped universal container. The specimens were labelled, transported to the microbiology laboratory and analysed within 6 hours. In each container boric acid $(0.2 \mathrm{mg})$ was added to prevent the growth of bacteria in urine samples. All patients were well instructed for proper collection of sample aseptically prior to sample collection to avoid contaminations from genital flora.

Verbal informed consent in local language was obtained from all patients prior to specimen collection. The sample was inoculated for semi-quantitative culture on Cystine-Lactose-Electrolyte-Deficient (CLED) media using a calibrated loop. The culture plates were incubated at $37^{\circ} \mathrm{C}$ for 18-24 hrs. under aerobic conditions. A specimen was considered positive for UTI when an organism was cultured at a concentration of $10^{4} \mathrm{cfu} / \mathrm{mL}$ and $>5$ pus cells per highpower field were observed on microscopic examination of the urine.(11) Identification of bacterial growth was determined by Gram's staining and standard microbiology techniques.

Gram negative bacteria were identified by the standard biochemical tests.(12,13) and Gram positive microorganisms were identified with the corresponding laboratory tests like catalase, coagulase and mannitol test for Staphylococcus aureus.(14)

The sensitivity of the strains against various antibiotics was determined by using antibiotic sensitivity discs, namely ceftazidime (CTZ) $30 \mathrm{mcg}$, cefotaxime (CTX) $30 \mathrm{mcg}$, cefepime (CPM) $50 \mathrm{mcg}$, piperacillin (PIT) 100/10 mcg, amoxyclav (AMC) $10 \mathrm{mcg}$, methicillin (MET) $30 \mathrm{mcg}$, penicillin G (PG) 10 units, ampicillin (AMP) $10 \mathrm{mcg}$, vancomycin (VA) $30 \mathrm{mcg}$, linezolid (LZ) $30 \mathrm{mcg}$, gentamicin (GEN) $50 \mathrm{mcg}$, amikacin (AK) $30 \mathrm{mcg}$, nalidixic acid (NA) $30 \mathrm{mcg}$, ciprofloxacin (CIP) 5 mcg, norfloxacin (NX) $10 \mathrm{mcg}$, co-trimoxazole (COT) $25 \mathrm{mcg}$, nitrofurantoin (NTF) $300 \mathrm{mcg}$, cefoxitin-30 $\mu \mathrm{g}$. The antibiotic characteristics of the 43 isolates were analysed by Kirby Bauer disk diffusion method.(15) as per NCCLS guidelines. For the staphylococcus strains, MRSA was detected by using cefoxitin-30 $\mu \mathrm{g}$ incubating at $35^{\circ} \mathrm{C}$. Minimum Inhibitory Concentration (MIC) $\geq 22 \mathrm{~mm}$ is considered as sensitive i.e. MSSA, whereas MIC $\leq 21 \mathrm{~mm}$ considered as MRSA. MIC for vancomycin was determined by agar dilution method (CLSI guidelines, 2011).(16)

\section{RESULTS}

Out of 401 samples processed 43 (10.7) gave significant growth pathogen. Out of 43 total isolates 35 (81\%) are from female patients, whereas $8(19 \%)$ are from male patients.

\begin{tabular}{|c|c|c|}
\hline $\begin{array}{c}\text { Total No. of } \\
\text { Isolates }\end{array}$ & Female & Male \\
\hline 43 & $35(81 \%)$ & $8(19 \%)$ \\
\hline \multicolumn{2}{|c|}{ Table 1: Showing the Total Number of Uropathogens } \\
\hline
\end{tabular}

Of the significant 43 isolates gram negative aerobic rods accounted for $74.4 \%$, whereas remaining $25.6 \%$ belonged to Gram positive cocci.

Among 43 isolates, Escherichia coli is the most prevalent organism (46.5\%), followed by Klebsiella pneumoniae (18.6\%), Proteus (4.05\%), Pseudomonas (4.65\%), Enterococcus spp. (16.2\%) and Staphylococcus aureus (9.3\%).

\begin{tabular}{|c|c|c|c|c|c|c|c|}
\hline Total No. of Samples & 401 & E. coli & K.pneumoniae & P.aeruginosa & Proteus mirabilis & S.aureus & $\begin{array}{c}\text { Enterococcus } \\
\text { spp. }\end{array}$ \\
\hline Isolates & 43 & 20 & 8 & 2 & 2 & 4 & 7 \\
\hline Percentage & & $46.5 \%$ & $18.6 \%$ & $4.65 \%$ & $4.65 \%$ & $9.3 \%$ & $16.27 \%$ \\
\hline
\end{tabular}

\begin{tabular}{|c|c|c|c|c|c|c|c|c|c|c|c|c|}
\hline \multirow[t]{2}{*}{ Antibiotics } & \multicolumn{2}{|c|}{ E.coli. ${ }^{20)}$} & \multicolumn{2}{|c|}{ K.pneumoniae. ${ }^{(8)}$} & \multicolumn{2}{|c|}{ P.aeruginosa.(2) } & \multicolumn{2}{|c|}{$\begin{array}{c}\text { Proteus } \\
\text { mirabilis. }{ }^{(2)}\end{array}$} & \multicolumn{2}{|c|}{ S.aureus. (4) } & \multicolumn{2}{|c|}{$\begin{array}{c}\text { Enterococcus } \\
\text { spp.(7) }\end{array}$} \\
\hline & $S$ & $\mathrm{R}$ & $\mathrm{S}$ & $\mathrm{R}$ & $S$ & $\mathrm{R}$ & S & $\mathrm{R}$ & $\mathrm{S}$ & $\mathrm{R}$ & $\mathrm{S}$ & $\mathrm{R}$ \\
\hline CTZ & 7 & 13 & 4 & 4 & 1 & 1 & 1 & 1 & NT & NT & NT & NT \\
\hline CTX & 7 & 13 & 4 & 4 & 1 & 1 & 1 & 1 & 3 & 1 & 6 & 1 \\
\hline CPM & 11 & 9 & 5 & 3 & 1 & 1 & 1 & 1 & NT & NT & NT & NT \\
\hline PIT & 16 & 4 & 6 & 2 & 2 & & 2 & & NT & NT & NT & NT \\
\hline AMC & 15 & 5 & 5 & 3 & 2 & & 2 & & NT & NT & NT & NT \\
\hline $\mathrm{PG}$ & NT & NT & NT & NT & NT & NT & NT & NT & & 4 & & 7 \\
\hline AMP & & 20 & NT & 8 & & 2 & & 2 & & & 2 & 5 \\
\hline VA & NT & NT & NT & NT & NT & NT & NT & NT & 4 & & 7 & \\
\hline $\mathrm{LZ}$ & NT & NT & NT & NT & NT & NT & NT & NT & 4 & & 7 & \\
\hline GEN & 14 & 6 & 5 & 3 & 2 & & 1 & 1 & 2 & 2 & 2 & 5 \\
\hline $\mathrm{AK}$ & 17 & 3 & 6 & 2 & 1 & 1 & 2 & & 4 & & NT & NT \\
\hline NA & 8 & 12 & 3 & 5 & 1 & 1 & & 2 & 2 & 2 & 1 & 6 \\
\hline CIP & 7 & 13 & 2 & 6 & 1 & 1 & 1 & 1 & 1 & 3 & 4 & 3 \\
\hline NX & 8 & 12 & 3 & 5 & 1 & 1 & 1 & 1 & 1 & 3 & 3 & 4 \\
\hline NIT & 17 & 3 & 7 & 1 & NT & NT & 2 & & 3 & 1 & 4 & 3 \\
\hline COT & 6 & 14 & 4 & 4 & NT & NT & 1 & 1 & 1 & 3 & NT & NT \\
\hline
\end{tabular}




\begin{tabular}{|c|c|c|c|c|c|c|c|c|c|c|c|c|}
\hline \multirow[t]{2}{*}{ Antibiotics } & \multicolumn{2}{|c|}{ E.coli. ${ }^{(20)}$} & \multicolumn{2}{|c|}{ K.pneumoniae.(8) } & \multicolumn{2}{|c|}{ P.aeruginosa.(2) } & \multicolumn{2}{|c|}{$\begin{array}{c}\text { Proteus. } \\
\text { mirabilis. }{ }^{(2)}\end{array}$} & \multicolumn{2}{|c|}{ S.aureus. ${ }^{(4)}$} & \multicolumn{2}{|c|}{ Enterococcus spp. ${ }^{(7)}$} \\
\hline & $S$ & $\mathrm{R}$ & $\mathrm{S}$ & $\mathrm{R}$ & $\mathrm{S}$ & R & $S$ & $\mathrm{R}$ & $S$ & $\mathrm{R}$ & $S$ & $\mathrm{R}$ \\
\hline CTZ & $35 \%$ & $65 \%$ & $50 \%$ & $50 \%$ & $50 \%$ & $50 \%$ & $50 \%$ & $50 \%$ & NT & NT & NT & NT \\
\hline CTX & $35 \%$ & $65 \%$ & $50 \%$ & $50 \%$ & $50 \%$ & $50 \%$ & $50 \%$ & $50 \%$ & $75 \%$ & $25 \%$ & $85.7 \%$ & $14.3 \%$ \\
\hline CPM & $55 \%$ & $45 \%$ & $62.5 \%$ & $37.5 \%$ & $50 \%$ & $50 \%$ & $50 \%$ & $50 \%$ & NT & NT & NT & NT \\
\hline PIT & $80 \%$ & $20 \%$ & $75 \%$ & $25 \%$ & $100 \%$ & & $100 \%$ & & NT & NT & NT & NT \\
\hline AMC & $75 \%$ & $25 \%$ & $62.5 \%$ & $37.5 \%$ & $100 \%$ & & $100 \%$ & & NT & NT & NT & NT \\
\hline$P G$ & NT & NT & NT & NT & NT & NT & NT & NT & & $100 \%$ & & $100 \%$ \\
\hline AMP & & $100 \%$ & & $100 \%$ & & $100 \%$ & & $100 \%$ & & & $28.5 \%$ & $71.5 \%$ \\
\hline VA & NT & NT & NT & NT & NT & NT & NT & NT & $100 \%$ & & $100 \%$ & \\
\hline LZ & NT & NT & NT & NT & NT & NT & NT & NT & $100 \%$ & & $100 \%$ & \\
\hline GEN & $70 \%$ & $30 \%$ & $62.5 \%$ & $37.5 \%$ & $100 \%$ & & $50 \%$ & $50 \%$ & $50 \%$ & $50 \%$ & $28.5 \%$ & $71.5 \%$ \\
\hline $\mathrm{AK}$ & $85 \%$ & $15 \%$ & $75 \%$ & $25 \%$ & $50 \%$ & $50 \%$ & $100 \%$ & & $100 \%$ & & NT & NT\% \\
\hline NA & $40 \%$ & $60 \%$ & $37.5 \%$ & $62.5 \%$ & $50 \%$ & $50 \%$ & & $\begin{array}{c}100 \\
\%\end{array}$ & $50 \%$ & $50 \%$ & $14.3 \%$ & $85.7 \%$ \\
\hline CIP & $35 \%$ & $65 \%$ & $25 \%$ & $75 \%$ & $50 \%$ & $50 \%$ & $50 \%$ & $50 \%$ & $25 \%$ & $75 \%$ & $57.1 \%$ & $42.8 \%$ \\
\hline NX & $40 \%$ & $60 \%$ & $37.5 \%$ & $62.5 \%$ & $50 \%$ & $50 \%$ & $50 \%$ & $50 \%$ & $25 \%$ & $75 \%$ & $42.8 \%$ & $57.1 \%$ \\
\hline NIT & $85 \%$ & $15 \%$ & $87.5 \%$ & $12.5 \%$ & NT & NT & $100 \%$ & & $75 \%$ & $25 \%$ & $57.1 \%$ & $42.8 \%$ \\
\hline COT & $30 \%$ & $70 \%$ & $50 \%$ & $50 \%$ & NT & NT & $50 \%$ & $50 \%$ & $25 \%$ & $75 \%$ & NT & NT \\
\hline
\end{tabular}

\section{DISCUSSION}

Among 401 urine samples processed 43 (10.7\%) samples were positive for uropathogens. It is almost similar to that of study conducted by Mohammed Akram et al.(17) in which it was $10.86 \%$. The prevalence of UTI occurred more in females than in males. Of 43 isolates $81 \%$ of the isolates are from female patients, whereas $19 \%$ are from male which is correlating with the study conducted by Afsana Fatema Noor et al.(18) as their study also showing the prevalence of female $79 \%$ and male $21 \%$. UTIs are caused by a variety of microorganisms including both gram positive and gram negative ones. The aetiology of UTI has been regarded as well-established and reasonably consistent. Out of 43 isolates the most prevalent organism is Escherichia coli, which is about $46.5 \%$, almost similar to that of in the study done by Rosa Daza et al.(19) showing $47 \%$ E. coli. The prevalence of Klebsiella spp. in present study was $18.6 \%$. This is very much similar to that of study conducted by Devanad Prakash et al.(20) showing the prevalence of Klebsiella $18.7 \%$.

In present study, isolation of P. aeruginosa was $4.6 \%$ which is in harmony with study conducted by Hari P Kattel et al.(21) showing the prevalence of Pseudomonas aeruginosa $5.01 \%$. Regarding the gram positive cocci, the prevalence of Enterococcus spp. is $16.27 \%$, which is correlating with the result of Amit A Rangari et al.(22) showing Enterococcus spp. as $20 \%$, which is just nearer to present study. In the present study the prevalence rate of Staphylococcus aureus is $9.3 \%$, which is same as that in the study conducted by Devanand Prakash et al.(20) in which the prevalence of S. aureus was 9.68\%. Drug resistance among uropathogens has increased over the past few decades because of their widespread indiscriminate use, easy availability and over the counter sale. This is heading us toward the use of higher spectrum antibiotics like amoxyclav, third generation cephalosporins and nitrofurantoin.(23)

Therefore, the magnitude of the problem should be accessed properly and in an accurate way. In present study $85 \%$ of the gram negative rods are susceptible to Nitrofurantoin, which can be compared with the study conducted by D. J. Farrell et al.(24) showing $96.3 \%$ and with study of Hari P Kattel et al.(21) which is showing $79.2 \%$ susceptibility to Nitrofurantoin.

\section{CONCLUSION}

Gram-negative bacteria were the major causes of urinary tract infection. Among them Escherichia coli were found significantly the most predominant than others. Majority of Gram-negative bacteria showed susceptibility towards Amikacin, Nitrofurantoin. Selection of antimicrobials for UTI should be guided by culture and sensitivity for empirical treatment.

\section{ACKNOWLEDGEMENT}

I am very much thankful to the management of Katuri Medical College and Hospital for their encouragement and support they have given to us to do this project work.

\section{REFERENCES}

1. Manjula NG, Girish C Math, Shripad A Patil. Incidence of urinary tract infections and its aetiological agents among pregnant women in Karnataka region. Advances in Microbiology

(http://www.scirp.org/journal/aim).

2. Gonzalez CM, Schaeffer AJ. Treatment of urinary tract infection: what's old, what's new, and what works. World Journal of Urology 1999;17(6):372-82.

3. Smita Sood, Ravi Gupta. Antibiotic resistance pattern of community acquired uropathogens at a tertiary care hospital in Jaipur, Rajasthan. Indian journal of community medicine 2012;37(1):39-44.

4. Nazar MS, Saldanha CL, Banday KA. Approach to urinary tract infections. Indian journal of nephrology 2009;19(4):129-39.

5. Shalini, Joshi MC, Rashid MK, et al. Study of antibiotic sensitivity pattern in urinary tract infection at a tertiary hospital. NJIRM 2011;2(3):43-6.

6. Komala M, Sampath Kumar KP. Urinary tract infection: causes, symptoms, diagnosis and it's management, Indian. Journal of Research in Pharmacy and Biotechnology ISSN: 2320-3471, 2013;1(2):226-33.

7. Janet M Torpy, Laura A Schwartz, Robert M Golub. Urinary tract infection. JAMA 2012;307(17):1877. doi:10.1001/jama.2012.3885.

8. Kim Gibson, Joseph Toscano. Urinary tract infection update. American Journal of Clinical Medicine, summer 2012;9(2). 
9. Syed Mustaq Ahmed, Ramakrishna Paijakribettu, Shaniya koyakutty, et al. Urinary tract infections-an overview on the prevalence and the anti-bio gram of gram negative uropathogens in a tertiary care centre in north Kerala, India. Journal of Clinical and Diagnostic Research 2012;6(7):1192-5.

10. Babypadmini S, Appalaraju B. Extended spectrumlactamases in the urinary isolates of escherichia coli and klebsiellapneumoniae-the prevalence and the susceptibility patterns in a tertiary care hospital. Indian Journal of Medical Microbiology 2004;22(3):172-4.

11. Collee G, Miles RS, Watt B. Tests for the identification of bacteria, inmackie and McArtney practical medical microbiology. JG Collee, AG Fraser, BP Marmion, and A Simmons, Eds. Churchill Livingstone, London, UK, 1996;p 433.

12. Foxman B, Brown P. Epidemiology of urinary tract infections: transmission and risk factors, incidence, and costs. Infectious Disease Clinics of North America 2003;17(2):227-41.

13. Foxman B, Barlow R, Arcy HD, et al. Urinary tract infection: self-reported incidence and associated costs. Annals of Epidemiology 2000;10(8):509-15.

14. Andreu A, Alós JI, Gobernado M, et al. Etiology and antimicrobial susceptibility among uropathogens causing community-acquired lower urinary tract infections: a nationwide surveillance study. Enfermedades Infecciosasy Microbiología Clínica 2005;23(1):4-9.

15. Sharma I, Paul D. Prevalence of community acquired urinary tract infections in silchar medical college, Assam, India and its antimicrobial susceptibility profile. Indian Journal of Medical Sciences 2012;66(11-12):273-9.

16. Wayne PA. Performance standards for antimicrobial susceptibility testing; 21 st informational supplement. CLSI 2011;31(1):p M100-S20.

17. Mohammed Akram, Mohammed Shahid, Asad U Khan. Etiology and antibiotic resistance patterns of community-acquired urinary tract infections is JNMC hospital aligarh, India. Annals of Clinical Microbiology and Antimicrobials 2007;6:4.
18. Afsana Fatema Noor, Fariza Shams, Saurab Kishore, et al. Prevalence and antibiogram profile of uropathogens isolated from hospital and community patients with urinary tract infections in dhaka city. Journal of Bangladesh academy of sciences 2013;37(1):57-63.

19. Rosa Daza, José Gutierrez, Gonzalo Piédrola. Antibiotic susceptibility of bacterial strains isolated from patients with community-acquired urinary tract infections. International Journal of Antimicrobial agents 2001;18(3):211-21.

20. Devanand Prakash, Ramchandra Sahai Saxena. Distribution and antimicrobial susceptibility pattern of bacterial pathogens causing urinary tract infection in urban community of Meerut City. ISRN Microbiology Article ID 749629, 2013;2013:pp 13.

21. Hari P Kattel, Jyoti Acharya, Shyam K Mishra, et al. Bacteriology of urinary tract infection among patients attending tribhuvan university teaching hospital kathmandu, Nepal. Journal of Nepal Association for Medical Laboratory Sciences 2008;9(1):25-9.

22. Amit A Rangari, Sachin Sharma, Nidhi Tyagi, et al. Antibiotic susceptibility pattern of bacterial uropathogensisolated from patients at a tertiary care hospitalin western Uttar Pradesh of India. International Journal of Current Microbiology and Applied Sciences 2015;4(10):646-57.

23. Kalantar E, Motlagh M, Lornejad H, et al. Prevalence of urinary tract pathogens and antimicrobial susceptibility patterns in children at hospitals in Iran. Iran J Clin Infect Dis 2008;3(3):149-53.

24. Farrell DJ, Morrissey I, De Rubeis D. A UK multicentre study of the antimicrobial susceptibility of bacterial pathogens causing urinary tract infection. Journal of Infection 2003;46(2):94-100. 